\title{
Bacterial recognition of thermal glycation products derived from porcine serum albumin with lactose
}

\author{
Andre-i Sarabia-Sainz', Gabriela Ramos-Clamont ${ }^{1}$, Joy Winzerling ${ }^{2}$ and \\ Luz Vázquez-Moreno ${ }^{1, \otimes}$
}

'Laboratorio de Bioquímica de Proteínas; Coordinación de Ciencia de los Alimentos, Centro de Investigación en Alimentación y Desarrollo A.C. (CIAD A.C.), Hermosillo, Sonora, Mexico; ${ }^{2}$ Department of Nutritional Sciences, University of Arizona, Tucson, United States

\begin{abstract}
Recently, glyco-therapy is proposed to prevent the interaction of bacterial lectins with host ligands (glycoconjugates). This interaction represents the first step in infection. Neoglycans referred to as PSA-Lac (PSA-Glu $(\beta 1-4)$ Gal) were obtained by conjugation of porcine serum albumin (PSA) with lactose at $80^{\circ} \mathrm{C}, 100^{\circ} \mathrm{C}$ and $120^{\circ} \mathrm{C}$. Characterization studies of the products showed that PSA could contain 1, 38 or 41 added lactoses, depending on the reaction temperature. These neoglycans were approximately 10 times more glycated than PSA-Lac obtained in previous work. Lactose conjugation occurred only at lysines and PSA-Lac contained terminal galactoses as confirmed by Ricinus communis lectin recognition. Furthermore, Escherichia coli $\mathrm{K}^{8}{ }^{+}, \mathrm{K} 88 \mathrm{ab}, \mathrm{K} 88 \mathrm{ac}$ and K88ad adhesins showed affinity toward all PSA-Lac neoglycans, and the most effective was the PSA-Lac obtained after $100{ }^{\circ} \mathrm{C}$ treatment. In vitro, this neoglycan partially inhibited the adhesion of $E$. coli $\mathrm{K}^{+} 8^{+}$to piglet mucin (its natural ligand). These results provide support for the hypothesis that glycated proteins can be used as an alternative for bioactive compounds for disease prevention.
\end{abstract}

Keywords: glycation of serum albumin, E. coli K88 adhesion, neoglycans, bacterial recognition

Received: 26 August, 2010; 11 December, 2010; accepted: 14 January, 2011; available on-line: 14 March, 2011

\section{INTRODUCTION}

Oligosaccharide chains of glycoconjugates on eukaryotic and prokaryotic cell surfaces form the first line of interaction with the extracellular world through their recognition by carbohydrate-binding proteins (Varki, 1993). These interactions mediate the adhesion of many pathogenic bacteria to the host cell as the initial step of infectious disease (Sharon \& Lis, 1989). Blocking of these interactions at an early stage following the exposure of the host to pathogens could prevent or reduce the infection (Sharon, 2006). One of the major drawbacks to the anti-adhesion therapy is the lack of appropriate glycoconjugates. Thus, the synthesis of glycoprotein moieties that mimic glycoconjugates, also referred to as neoglycoconjugates, represents an alternative strategy to produce single glycoforms for anti-adhesion use (Wong, 1995). The development of a simple and low cost process for neoglycoconjugate synthesis by chemical means has been viewed with skepticism because of the complexity of glycan molecules. Nevertheless, previous work has shown that glycation based on the Maillard reaction can serve as the basis for the synthesis of neoglycans as tools that can be used for biological recognition (Stowell \& Lee, 1978; Boratynski \& Roy, 1998).

The early stage chemistry of non-enzymatic protein glycation involves an initial nucleophilic substitution reaction between sugar carbonyl groups and amino groups of proteins to form a Schiff's base that undergoes spontaneous changes known as the Amadori rearrangement (Singh et al., 2001). Controlled and limited glycation at this point enables a direct attachment to protein without any prior modification or chemical activation of the reagents (Ledesma-Osuna et al., 2008). Sarabia-Sainz et al. (2009) and Ledesma-Osuna et al. (2008) demonstrated that lactosylated porcine serum albumin (PSA) neoglycans obtained by Maillard reaction interact with galactose-specific K88 adhesin. This microbial lectin expressed on the Escherichia coli K88 cell surface is responsible for the initial infection of piglets that results in diarrhea. A definition of the reaction conditions of glycation, such as temperature, water activity and time of reaction, is necessary for neoglycan synthesis optimization in order to obtain neoglycans that can be used to prevent or deter E. coli K88 adhesion to piglet intestine cell surfaces, and thereby reduce infection. Here the effect of temperature in PSA glycation with lactose was studied.

\section{MATERIALS AND METHODS}

Materials. PSA was purchased from Pel-Preez Biologicals (Arkansas, USA). Biotin-labeled Ricinus communis lectin was from Vector (Burlingame, CA, USA) and BSA-Gal $\propto$ (1-3) Gal was acquired from Glycorex (Sweden). All other chemicals were analytical grade from Sigma-Aldrich (St Louis, MO, USA).

Preparation of glycated proteins. Glycation of PSA was conducted according to Kańska and Boratyński (2002) with minor modifications. Briefly, $80 \mathrm{mg}$ of PSA (in $10 \mathrm{mM}$ phosphate buffer, $\mathrm{pH}$ 6.5) was mixed with $80 \mathrm{mg}$ of D-lactose to attain 1:200 molar ratio. Samples

e-mail lvazquez@ciad.mx

Abbreviations: ATCC, American type culture collection; BSA, bovine serum albumin; cfu, colony-forming unit; ELLA, enzyme-linked lectin assay; ELISA, enzyme-linked immunosorbent assay; HPLC, high-performance liquid chromatography; LC-MS/MS, liquid chromatography coupled to tandem mass spectrometry; MALDI PBS, phosphate-buffer saline; PSA, porcine serum albumin; PSA-Lac, lactosylated porcine serum albumin; RCA I, Ricinus communis agglutinin I; RH, relative humidity; TPBS, Tween-phospate buffer saline; ToF, matrix-assisted laser desorption/ionization-time of flight; TFA, trifluoroacetic acid. 
were frozen at $-40^{\circ} \mathrm{C}$ and freeze-dried (Virtis Benchop 6.6, NY, USA). Portions of the resulting powder (each of $20 \mathrm{mg}$ ) were incubated at $80^{\circ} \mathrm{C}, 100^{\circ} \mathrm{C}$ and $120^{\circ} \mathrm{C}$ for $30 \mathrm{~min}$. Heat treatments were interrupted by the addition of cold double-distilled water. Free lactose was removed by extensive dialysis in double-distilled water at $4^{\circ} \mathrm{C}$. Finally, samples were freeze-dried and stored (in sealed containers) at $-20^{\circ} \mathrm{C}$ until further analysis.

Polyacrylamide gel electrophoresis. PSA and PSALac neoglycans were analyzed under denaturing and reducing conditions using $10 \%$ polyacrylamide gels (SDS/ PAGE) according to Laemmli (1970). Samples containing $10 \mu \mathrm{g}$ of proteins were loaded to gels, and stained with $1 \%$ Coomassie blue in $30 \%$ methanol and $10 \%$ acetic acid.

Spectrometry analysis. PSA and PSA-Lac neoglycans were sent to the Arizona Proteomics Consortium (Proteomic Services, University of Arizona, USA) for molecular mass determination by MALDI-ToF. Mass spectra were acquired using an Applied Biosystems Voyager DE-STR (Framinham, MA, USA), operating a $337 \mathrm{~nm}$ nitrogen laser. Samples were resuspended in a solution containing $0.1 \%$ of trifluoroacetic acid (TFA) to give final concentration of $2 \mu \mathrm{g} / \mu \mathrm{L}$. Samples $(5 \mu \mathrm{L})$ were mixed with $5 \mu \mathrm{L}$ of a saturated $\alpha$-cyano4-hydroxy-cinnamic acid solution in $50 \%$ acetonitrile $/ 50 \%$ water containing $0.1 \%$ of TFA, and $1 \mu \mathrm{L}$ was spotted on the target plate and allowed to air-dry prior to mass analysis. Mass spectra were collected in linear mode with an accelerating voltage of $25000 \mathrm{~V}$.

Enzymatic digestion of neoglycans. For identification of carbohydrate-modified amino acids, untreated PSA and PSA-Lac $100{ }^{\circ} \mathrm{C}$ were digested with 1 $\mathrm{mg} / \mathrm{mL}$ solution of trypsin (Shevchenko et al., 1996). Liquid chromatography coupled to tandem mass spectrometry (LC-MS/MS) was performed on the protease-treated samples. One microgram of digested protein was injected onto a linear quadrupole ion trap ThermoFinnigan LTQ mass spectrometer (San Jose, CA, USA) equipped with a Michrom Paradigm MS4 HPLC, a SpectraSystems AS3000 autosampler, and a nanoelectrospray source. Peptides eluted from a $15 \mathrm{~cm}$ pulled tip capillary column using a gradient of $0-65 \%$ solvent B (98\% methanol/ 2\% water $/ 0.5 \%$ formic acid $/ 0.01 \%$ trifluoroacetic acid) over a $60 \mathrm{~min}$ period at a flow rate of $350 \mathrm{~mL} / \mathrm{min}$. Mobil phase (solvent A) included $0.5 \%$ formic acid and $0.01 \%$ trifluoroacetic acid in water. The LTQ electrospray positive mode spray voltage was set at $1.6 \mathrm{kV}$, and the capillary temperature at $180^{\circ} \mathrm{C}$. Data scanning was performed by the Xcalibur v1.4 software (Andon et al., 2002). Lactose-modified peptides were identified by comparison with peptides of unmodified PSA.

Enzyme linked lectin recognition assays (ELLA assays). Recognition of PSA-Lac by biotin-labeled RCA1 lectin (specific for galactose) was done by Enzyme-linked lectin assay (ELLA) according to SarabiaSainz et al. (2009). Briefly, polystyrene ELISA microtitre plates were coated with $100 \mu \mathrm{L}$ of diluted solutions of PSA-Lac treatments in $50 \mathrm{mM}$ sodium bicarbonate buffer ( $\mathrm{pH}$ 9.5). PSA-Lac solutions were serially diluted (from 25 to $1 \mathrm{ng}$ ), applied to ELISA plate wells and incubated for $16 \mathrm{~h}$ at $4^{\circ} \mathrm{C}$. Following adsorption, wells were blocked for $3 \mathrm{~h}$ with $20 \mathrm{mM}$ phosphate buffered saline containing, $0.05 \%$ Tween 20, pH 7.5 (TPBS) and $1.5 \%$ BSA. Aliquots $(100 \mu \mathrm{L})$ of biotinylated RCA1 lectin $(5 \mu \mathrm{g} / \mathrm{mL})$ in PBS, pH 7.5, were added and incubated for $2 \mathrm{~h}$. After washing with TPBS, the plates were incubated with avidin-peroxidase $(1: 1000, \mathrm{v} / \mathrm{v}$, in PBS, $\mathrm{pH}$ 7.5) for $1 \mathrm{~h}$, and o-phenylendiamine was used to reveal lectin binding. Color development was stopped after $10 \mathrm{~min}$ by adding $100 \mu \mathrm{L}$ of $0.5 \mathrm{M} \mathrm{H}_{2} \mathrm{SO}_{4}$ and solution absorbance was measured using an ELISA 680 microplate reader (BioRad, CA, USA) at $450 \mathrm{~nm}$.

Piglet mucin isolation. Duodenum sections from nine healthy piglets (17 days old) were obtained and mucins released according to Sarabia-Sainz et al. (2009).

E. coli $\mathrm{K} 88$ growth. E. coli $\mathrm{K} 88^{+}$strains isolated from pigs, kindly donated by Dr. Carlos Eslava from Universidad Nacional Autonoma de Mexico, and E. coli subtypes (K88ab, K88ac and K88ad) from American Type Culture Collection (ATCC) were maintained as frozen stocks. Overnight cultures grown in Nutrient Broth (DIFCO), using a shaker at $37^{\circ} \mathrm{C}$, were harvested by centrifugation. Bacteria pellets were washed twice in PBS, pH 7.5 and suspensions adjusted to 0.4 units of optical density at $600 \mathrm{~nm}$ (about $2 \times 10^{8} \mathrm{cfu}$ $\mathrm{mL}^{-1}$ ) before use.

E. coli K88 adhesion assays (ELLA). ELLA assays were conducted according to Yacoby et al. (2007) with minor modification. Briefly, $100 \mu \mathrm{L}$ of E. coli ${\mathrm{K} 88^{+}}^{+}$ suspensions $\left(2 \times 10^{8} \mathrm{cfu} \mathrm{mL}^{-1}\right)$ were applied to ELISA plate wells and fixed with $1 \%$ glutaraldehyde (in PBS, $\mathrm{pH}$ 7.5) for $2 \mathrm{~h}$. After three TPBS washes, nonspecific interactions were blocked for $1 \mathrm{~h}$ with TPBS containing $1.5 \% \mathrm{BSA}$, and further incubated for $2 \mathrm{~h}$ with 100 $\mu \mathrm{L}$ of biotin-labeled PSA-Lac $(10 \mu \mathrm{g} / \mathrm{mL})$ heat-treated or not. Following two TPBS washes, the plates were incubated with streptavidin-peroxidase $(1: 1000)$ for $1 \mathrm{~h}$ and o-phenylendiamine was used to detect bacterial adhesion. Color development was stopped after $10 \mathrm{~min}$ by adding $100 \mu \mathrm{L}$ of $0.5 \mathrm{M} \mathrm{H}_{2} \mathrm{SO}_{4}$. Absorbance was measured as described before (Sarabia-Sainz et al., 2009). ELLA assays were also conducted with the different E. coli K88 variants (K88ab, K88ad, and K88ad) and PSA-Lac glycated at $100^{\circ} \mathrm{C}$.

Inhibition of $E$. coli $\mathrm{K}^{+}$adhesion to piglet mucins. To test for inhibition of adhesion of E. coli ${\mathrm{K} 88^{+}}^{+}$ to piglet mucins by PSA-Lac, $50 \mu \mathrm{g}$ of intestinal piglet mucin was immobilized at concentrations of $50 \mu \mathrm{g}$ in ELISA plates for $16 \mathrm{~h}$ at $4^{\circ} \mathrm{C}$. Subsequently, biotin-la-

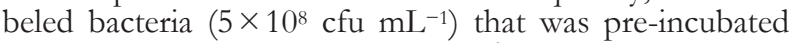
for $1 \mathrm{~h}$ with $\mathrm{PSA}-\mathrm{Lac}-100^{\circ} \mathrm{C}(3 \mu \mathrm{g} / \mu \mathrm{L})$ at room temperature was overlaid on the ELISA plate wells and detection proceeded as described for the lectin assays.

\section{RESULTS AND DISCUSSION}

\section{Evaluation of PSA glycation}

SDS/PAGE under reducing conditions was used to evaluate the extent of PSA glycation (Fig. 1A). PSA heated in the presence of lactose showed a temperaturedependent reduction of migration (mass increment). PSA-Lac $80^{\circ} \mathrm{C}$ showed (Fig. 1A, lane 2) slight reduction of migration when compared to native PSA (Fig. 1A, lane 1). Glycation at $100^{\circ} \mathrm{C}$ or $120^{\circ} \mathrm{C}$ are products with a greater mass (Fig. 1A, lanes 3 and 4).

The PSA-Lac products glycated at $100{ }^{\circ} \mathrm{C}$ presented two electrophoretic bands with different mobility and staining intensity: a darker band with an approx. $10 \%$ increase in apparent molecular mass and a faint band that corresponded to a mass increment increase of about 18\% (Fig. 1A, lane 3). These results suggested that glycation under these conditions led to the formation of products with different number of lactose. 


\section{Mass determination}

Mass spectroscopy has been used to assess protein molecular masses and is one of the best methods to estimate mass changes such as those resulting from protein modifications (Kislinger et al., 2002; Sun et al., 2005). MALDI-ToF MS was used to evaluate the molecular mass of PSA glycated at different temperatures. The spectra of untreated and glycated PSA products are shown in Fig. 1B-E. Their comparison reveals clear differences. The most abundant molecular ion of native PSA was $66384.01 \mathrm{~m} /$ z. (Fig. 1B). PSA-Lac glycated at $60^{\circ} \mathrm{C}$ showed the same spectra as that of native PSA (not shown) indicating no lactose addition to PSA at this temperature. However, under all other temperature conditions, an increased PSA molecular mass was observed. The most abundant ion of PSA-Lac glycated at $80^{\circ} \mathrm{C}$ (Fig. 1C) had an $m / z$ of 66785.49. PSA-Lac produced by incubation at $100^{\circ} \mathrm{C}$ (Fig. 1D) yielded two main ions. Peak maximum was found at $66422.80 \mathrm{~m} / \mathrm{z}$, and a broad and heterogeneous peak with approximate maximum at $78323.85 \mathrm{~m} / \mathrm{z}$ was also present. The resulting mass differences of PSA-Lac formed at $100^{\circ} \mathrm{C}$ are probably results of multiple modifications with lactose, primarily reflecting the heterogeneity of Maillard reaction (Chevalier et al., 2002) and are in agreement with the electrophoretic patterns data (Fig. 1A, lane 5). The spectrum of PSA-Lac glycated at $120^{\circ} \mathrm{C}$ also showed a heterogeneous peak with a maximum of $79790.64 \mathrm{~m} / \mathrm{z}$ (Fig. 1E). MALDI-ToF MS data confirmed the electrophoretic analysis

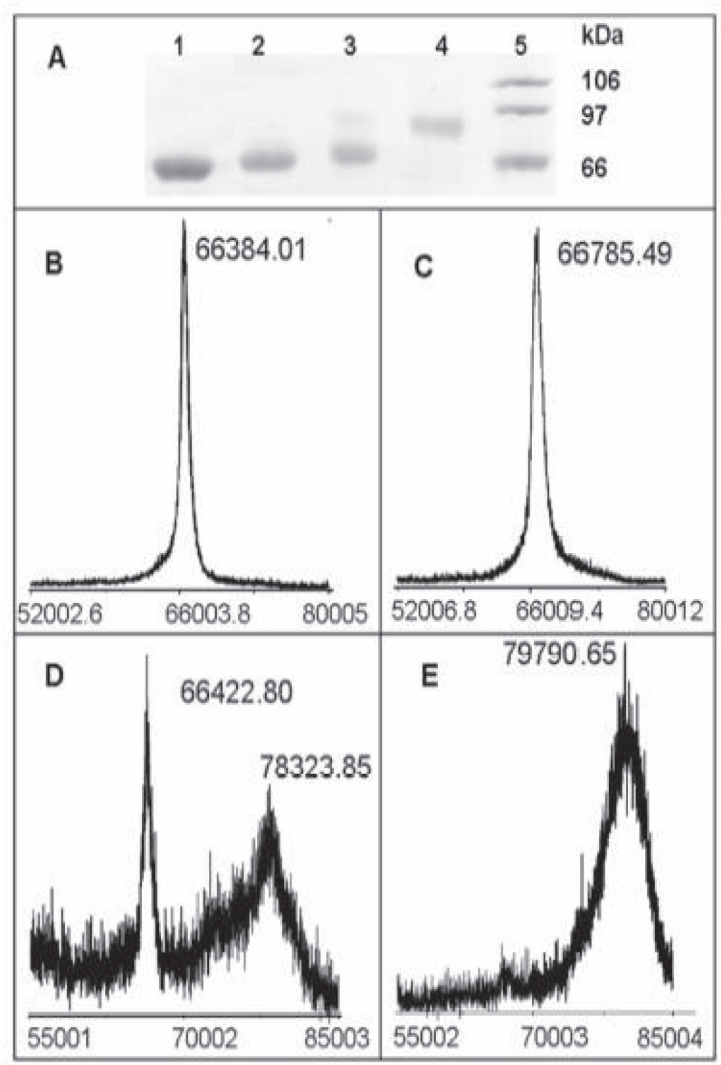

Figure 1. Mass spectra by MALDI ToF of PSA-Lac obtained at various temperatures

(A) SDS/PAGE of PSA treated at various temperatures. Lane 1, PSA untreated; Lanes $2,3,4, \mathrm{PSA}$ glycated with lactose at $80^{\circ} \mathrm{C}, 100^{\circ} \mathrm{C}$ and $120^{\circ} \mathrm{C}$, respectively; Lane 5 , molecular mass standards. (B) MALDI ToF mass spectra for PSA untreated; (C) PSA-Lac $80^{\circ} \mathrm{C}$; (D) PSA-Lac $100^{\circ} \mathrm{C} ;$ (E) PSA-Lac $120^{\circ} \mathrm{C}$. and demonstrated that the higher the temperature of reaction the greater the product mass.

A summary of the molecular masses of the most abundant ions in the treatment of PSA-Lac and the number of lactoses added by each treatment is shown in Table 1. PSA-Lac heated at $80^{\circ} \mathrm{C}$ for $30 \mathrm{~min}$ presented addition of one lactose, while the glycation treatments at the higher temperatures $\left(100^{\circ} \mathrm{C}\right.$ and $\left.120^{\circ} \mathrm{C}\right)$ were more effective, adding 38 and 41 molecules of lactose to PSA, respectively. The level of PSA glycation was higher for this study than for our previous work where four lactose molecules were added to PSA-Lac (Sarabia-Sainz et al., 2009) using the method described by Fenaille et al. (2002). Fenaille et al. (2002) used solid-state synthesis of neoglycans that involved protein glycation under conditions of controlled relative humidity (RH) at $25^{\circ} \mathrm{C}$ for 7 days, followed by heat treatment for different periods of time. Thus, the modified method of Kańska and Boratyński (2002) used in this study is less time consuming and more efficient for the synthesis of PSA-Lac neoglycans. PSA-Lac $100^{\circ} \mathrm{C}$ was chosen for subsequent work.

\section{Sites of glycation}

In proteins, the N-terminal amino acid, lysines (Lys) and arginines (Arg) are the most frequently glycated amino acids. PSA primary sequence has 58 Lys and 33 Arg residues that are available for carbohydrate conjugation. However, Sarabia-Sainz et al. (2009) have shown that Lys is the most frequently modified amino acid. To determine sites of glycation, PSA-Lac $\left(100^{\circ} \mathrm{C}\right)$ was treated with trypsin, and the peptides and glycopeptides were identified and sequenced by mass spectrometry. Figure 2 shows the sequence of peptides where Lys residue(s) were glycated. Under these conditions, neither Arg nor the N-terminal amino acids were modified. PSA-Lac glycated at $100^{\circ} \mathrm{C}$ contained 37 Lys residues modified with lactose (indicated in bold), while 21 remained intact. Further data analysis showed that in PSA-Lac twenty Lys that had neighboring hydrophobic residues and eight pairs of adjacent Lys were glycated. The accessibility of amino-acid residues appears to play an important role in protein glycation (Nacharaju \& Acharya, 1992). The site selectivity of glycation in proteins is suggested to be a consequence of the three dimensional structure that determines the availability of amino acids to bind carbohydrates (Nacharaju \& Acharya, 1992), as well as the ability of a given site to undergo the Amadori rearrangement (Acharya et al., 1983). The latter capacity, in turn, depends on molecular microenvironmental conditions. Other factors have also been shown to be important including the facility for Amadori rearrangement formation at the glycation sites (Shapiro et al., 1980), and the nature

Table 1. Molecular mass of most abundant ions for PSA-Lac and numbers of lactose units added on glycated PSA

\begin{tabular}{lcc}
\hline Treatment & Molecular mass $(\mathrm{Da})$ & Lactoses added $^{\mathrm{b}}$ \\
\hline PSA untreated & 66384.01 & - \\
PSA-Lac $80^{\circ} \mathrm{C}$ & 66785.49 & 1 \\
PSA-Lac $100^{\circ} \mathrm{C}$ & 66422.80 and 78323.85 & 0 and 38 \\
PSA-Lac $120^{\circ} \mathrm{C}$ & 79790.65 & 41 \\
\hline
\end{tabular}

aMass of most abundant ion. ${ }^{\circ}$ To determine the number of carbohydrate molecules conjugated, mass difference (glycated-untreated PSA) was divided by $324 \mathrm{Da}$ (lactose residue mass). 


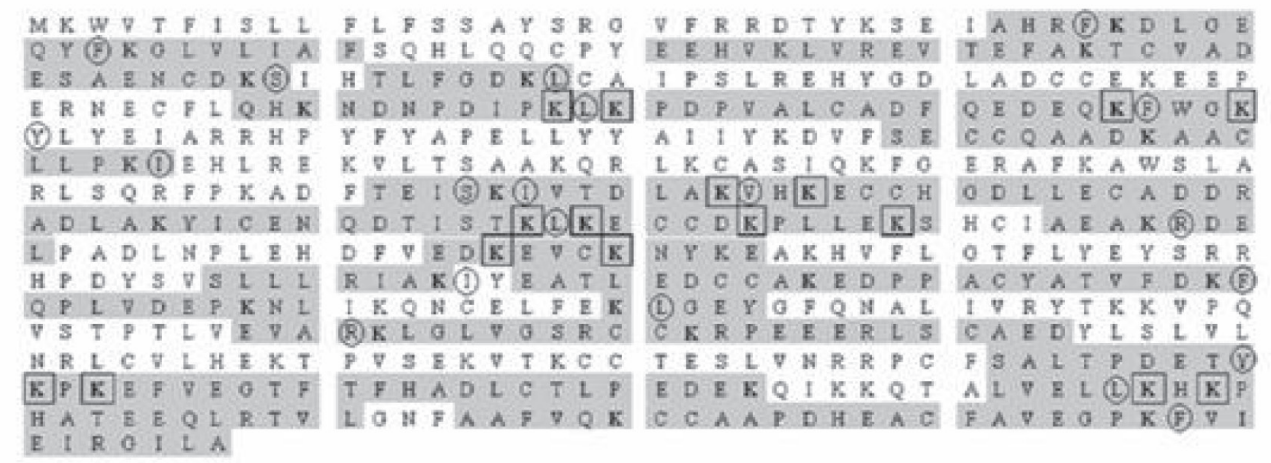

Figure 2. Peptide mapping by mass spectroscopy of lysine residues modified in PSA-Lac $100^{\circ} \mathrm{C}$.

Peptide sequences were determined from trypsin digestion of PSA-Lac $100^{\circ} \mathrm{C}$. K, Lysines modified with lactose. O, Vicinal hydrophobic amino acids. $\mathrm{O} \square$ = Pairs of glycated $\mathrm{K}$.

of amino-acids surrounding the Lys residues (Baynes et al., 1989). The most reactive Lys residues appear to be near hydrophobic amino acids in the primary structure (Mennella et al., 2006). Further, the proximity of another Lys in the primary structure has been reported to promote human serum albumin glycation (Garlick \& Mazer, 1983). In this study, the addition of multiple lactoses to PSA-Lac at $100^{\circ} \mathrm{C}$ probably was influenced by the reaction temperature (Kańska \& Boratyński, 2002).

\section{Recognition of PSA-Lac by soluble lectin assay (ELLA assays)}

Except for monosaccharides, the conjugation of carbohydrates to protein makes them susceptible to biological recognition by plant lectins (Blome \& Schengrund, 2008; Ledesma-Osuna et al., 2008). ELLA assays were used to confirm that galactose residues were available from the produced neoglycans. PSA-Lac obtained at $100^{\circ} \mathrm{C}$ and $120^{\circ} \mathrm{C}$ were strongly recognized by RCA 1 lectin (specific for $\beta$-galactose), while glycation products produced at $80^{\circ} \mathrm{C}$ presented similar interaction as

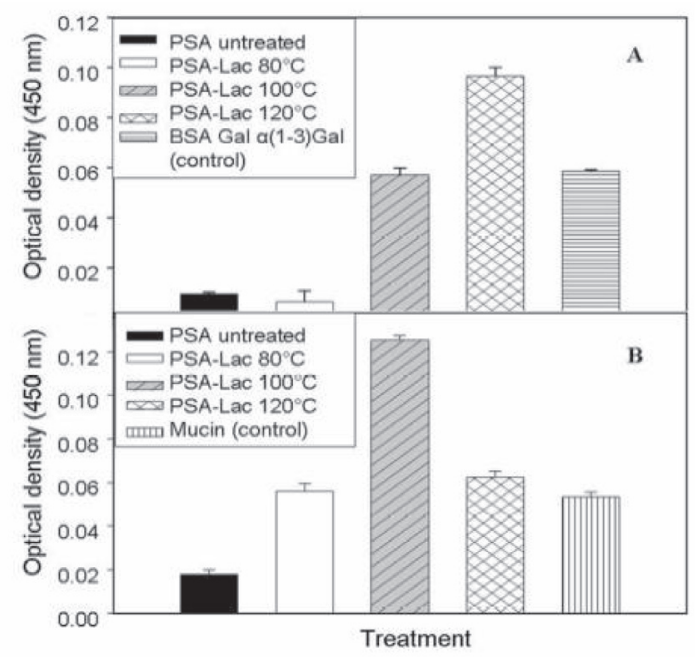

Figure 3. (A) ELLA assay for the recognition of PSA-Lac by Ricinus communis lectin

Protein $(3 \mu \mathrm{g})$ was adsorbed in ELISA plate wells, then overlaid with biotinylated RCA lectin. (B) ELLA assay for interaction of $E$. coli $\mathrm{K}^{+} 8^{+}$and PSA-Lac. Bacteria was adjusted to 0.5 units of absorbance $(660 \mathrm{~nm})$ and $100 \mu \mathrm{L}$ were adsorbed in ELISA plate wells, then overlaid with biotinylated piglet mucin, biotinylated untreated PSA or biotinylated PSA-Lac. did untreated PSA (Fig. 3A). PSA glycated at $80^{\circ} \mathrm{C}$ has only one carbohydrate ligand that appeared unavailable to interact with the lectin. Meanwhile, PSA-Lac $120^{\circ} \mathrm{C}$ showed higher interaction than BSA-Gal $\alpha(1-3)$ Gal (positive control). This commercial neoglycan has 10-15 spacer arms with terminal galactoses that are recognized by RCA (Sarabia-Sainz et al., 2009). PSA-Lac $100^{\circ} \mathrm{C}$ (38 lactoses) matched the degree of interaction between the lectin and BSA-Gal $\alpha(1-3)$ Gal. This observation also suggests that not all galactoses have the same exposure.

Glycation with lactose (galactose- $\beta(1-4)$-glucose) produced covalent binding of the reducing sugar (glucose) with the amino group side chain of Lys residues of PSA. The product makes galactose available for recognition. In this context, this study data substantiate that the method used here for the glycation of PSA did not alter the structure of galactose, and further, confirms that optimal lactose addition to albumin occurs at higher temperatures. In contrast, glycation by glucose can occur at lower temperatures, as is the case for proteins in the blood of diabetic patients; however, this modification is not recognized by plant lectins (Ledesma-Osuna et al., 2008).

\section{Bacterial adhesin recognition}

The interaction between E. coli $\mathrm{K} 88^{+}$adhesin and PSA-Lac neoglycans was established using a modified ELLA assay. Bacteria was immobilized in ELISA plates using glutaraldehyde, subsequently adhesin interaction with neoglycans was evaluated (Fig. 3B). Positive control included piglet intestine mucin, the natural ligand for $\mathrm{K} 88^{+}$adhesin, and untreated PSA (negative control). All PSA-Lac treatments were recognized by bacterial adhesins and PSA-Lac $100^{\circ} \mathrm{C}$ showed the strongest signal. E. coli adhesins also interacted with PSA-Lac $80^{\circ} \mathrm{C}$ and PSA-Lac $120^{\circ} \mathrm{C}$, as well as with mucin. PSA showed a slight association, probably due to nonspecific binding activity (He et al., 2006).

As opposed to ELLAs with RCA1 lectin where PSA glycated at $120^{\circ} \mathrm{C}$ was more readily recognized than that prepared at $100^{\circ} \mathrm{C}$, in adhesin assays, PSA-Lac $100^{\circ} \mathrm{C}$ interaction was greater. This behavior could be attributed to albumin aggregation at the higher glycation temperature $\left(120^{\circ} \mathrm{C}\right)$, that interfered with the bacterial adhesion. Alternatively with the soluble lectin, its size likely also facilitates or hinders interaction with the ligand (Sharon \& Lis, 1989).

The antigenic serological variants of K88 adhesin (K88ab, K88ac and K88ad) result in a small number of 


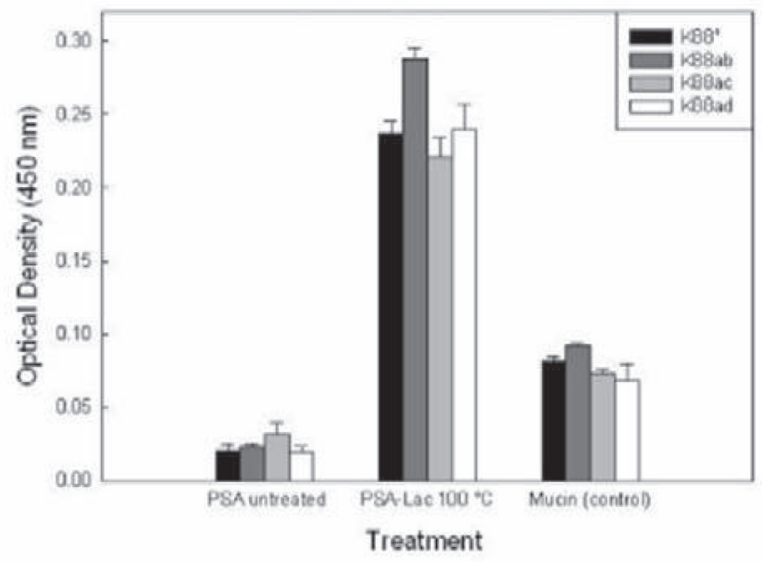

Figure 4. ELLA assay for interaction of PSA-Lac $100^{\circ} \mathrm{C}$ in the E. coli adhesins variants

E. coli variants (K88+, K88ab, K88ac, K88 ad) were adjusted at 0.5 units of optical density $(660 \mathrm{~nm})$ and $100 \mu \mathrm{L}$ were adsorbed in ELISA plate wells; then overlaid with biotinylated piglet mucin, biotinylated untreated PSA or biotinylated PSA-Lac.

amino acid substitutions that conferred on them a different, but related, carbohydrate-binding specificity (Willemse \& Graaf, 1992; Verdonck et al., 2004). Grange et al. (2002) showed that all variants of K88 recognize structures ending in galactose $\beta$ links, such as in lactose. PSA products were used to test for E. coli adhesion variants' interactions. Figure 4 shows that PSA-Lac $100^{\circ} \mathrm{C}$ was recognized by all three E. coli adhesin variants. However interaction was greater with K88ab. The adhesins also interacted with piglet mucin but with lower affinity. Thus, it is noteworthy that PSA-Lac $100^{\circ} \mathrm{C}$ presented a higher affinity for E. coli K88 than did mucin, and this also confirms that lactose neoglycans can be used as a ligand for E. coli K88 binding.

\section{Inhibition of adhesion of $E$. coli $\mathrm{K88}^{+}$adhesin to its natural host}

One of the main strategies proposed to prevent bacterial infections has been to use soluble glycoproteins

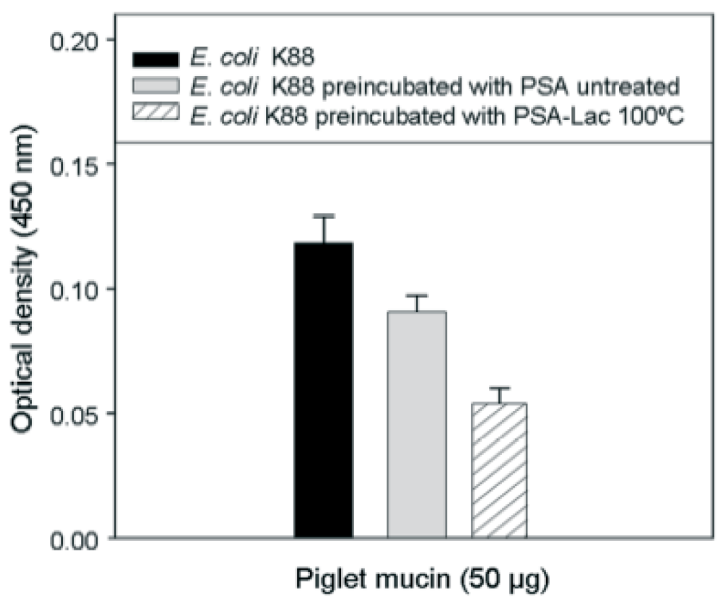

Figure 5 . Inhibition of adhesion by $E$. coli $\mathrm{K}^{8} 8^{+}$to piglet mucin by PSA-Lac

Mucins $(50 \mu \mathrm{g})$ were adsorbed in ELISA plate wells, then bacteria (pre-incubated for $1 \mathrm{~h}$ with buffer alone, with untreated PSA or with $300 \mu \mathrm{g}$ of PSA-Lac $100^{\circ} \mathrm{C}$ ) were added to plates. Inhibition was detected as described in Materials and Methods. that function as ligands for bacterial adhesins to block the interaction of pathogens with host cells (Sharon \& Lis, 1989). In this context, an ELLA assay was designed to evaluate this strategy. E. coli $\mathrm{K}^{+} 8^{+}$was pre-incubated with PSA-Lac $100^{\circ} \mathrm{C}$; then allowed to interact with immobilized mucin on an ELISA plate. Under these conditions, recognition of mucin by bacteria was drastically decreased by pretreatment with PSA-Lac. PSA-Lac was able to reduce (approx. 80\%) the bacteria adhesion to piglet mucins (Fig. 5). Similar results were obtained with K88ab, ac and ad adhesins (not shown). Untreated PSA presented some non-specific interaction with E. coli $\mathrm{K}_{88}{ }^{+}$.

\section{CONCLUSION}

This study indicates that non-enzymatic lactosylation of PSA produces neoglycans that are recognized by the galactose-specific E. coli K88 adhesins. Further, these glycoconjugates inhibited bacterial adhesion to piglet mucin in vitro. In vivo studies will be required to support the hypothesis that neoglycans obtained can prevent diarrhea in piglets caused by E. coli K88.

\section{Acknowledgements}

We are grateful to the National Council of Sciences and Technology of Mexico, CONACYT, for the financial support for this research, under project P47998-Q, as well as for the scholarship for Ph.D. studies awarded. This work was supported as well by the College of Agriculture and Life Sciences and the Agricultural Experiment Station at the University of Arizona (USA).

\section{REFERENCES}

Acharya AS, Sussman LG, Manning JM (1983) Schiff base adducts of glyceraldehyde with hemoglobin. differences in the Amadori rearrangement at the alpha-amino groups. I Biol Chem 258: 2296-2302.

Andon NL, Hollingworth S, Koller A, Greenland AJ, Yates JR, Hanes PA (2002) Proteomic characterization of wheat amyloplasts using identification of proteins by tandem mass spectrometry. Proteomics 2: 1156-1168.

Baynes JW, Watkins NG, Fisher CI, Hull CJ, Patrick JS, Ahmed MU, Dunn JA, Thorpe SR (1989) The Amadori product on protein: structure and reactions. Prog Clin Biol Res 304: 43-67.

Blome MC, Schengrund CL (2008) Multivalent binding of ricin to bovine serum albumin-based neoglycoconjugates Toxicon 51: 1214 1224.

Boratynski J, Roy R (1998) High temperature conjugation of proteins with carbohydrates. Glycoconj J 15: 131-138.

Chevalier F, Chobert JM, Dalgalarrondo M, Choiset M, Haertle T (2002) Maillard glycation of beta-lactoglobulin induces conformation changes. Nabrung 46: 58-63.

Fenaille F, Morgan F, Parisod V, Tabet JC, Guy PA (2003) Solid-state glycation of beta-lactoglobulin monitored by electrospray ionisation mass spectrometry and gel electrophoresis techniques. Rapid Commun in Mass Spectrom 17: 1483-1492.

Garlick RL, Mazer JS (1983) The principal site of nonenzymatic glycosylation of human serum albumin in vivo. I Biol Chem 258: 61426146.

Grange P, Mouricout M, Levery S, Francis D, Erickson A (2002) Evaluation of receptor binding specificity of Escherichia coli K88 (F4) fimbrial adhesin variants using porcine serum transferrin and glycosphingolipids as model receptors. Infect Immun 70: 2336-2343.

He Y, Rozak DA, Sari N, Chen Y, Bryan P, Orban J (2006) Structure, dynamics, and stability variation in bacterial albumin binding modules: implications for species specificity. Biochemistry 45: 1010210109

Kańska U, Boratyński J (2002) Thermal glycation of proteins by Dglucose and D-fructose. Arch Immunol Ther Exp (Warsy) 50: 61-66.

Kislinger T, Humeny A, Seeber S, Becker C, Pischetsrieder C (2002) Qualitative determination of the early maillard-products by MALDIToF mass spectrometry peptide mapping. Eur Food Res Technol 215: 65-71. 
Laemmli UK (1970) Cleavage of structural proteins during the assembly of the head of bacteriophage T4. Nature 227: 680-685.

Ledesma-Osuna AI, Ramos-Clamont G, Vázquez-Moreno L (2008) Characterization of bovine serum albumin glycated with glucosa, galactose and lactose. Acta Biochim Pol 55: 491-497.

Mennella C, Visciano M, Napolitano A, Del Castillo MD, Fogliano V (2006) Glycation of lysine-containing dipeptides. I Peptide Sci 12: 291-296.

Nacharaju P, Acharya AS (1992) Amadori rearrangement potential of hemoglobin at its glycation sites is dependent on the three-dimensional structure of protein. Biochemistry 31: 12673-12679.

Sarabia-Sainz A, Ramos-Clamont G, Candia-Plata MC, Vázquez-Moreno L (2009) Biorecognition of Escherichia coli K88 adhesin for glycated porcine albumin. Int J Biol Macromol 44: 175-181.

Shapiro R, McManus MJ, Zalut C, Bunn HF (1980) Sites of nonenzymatic glycosylation of human hemoglobin A. J Biol Chem 255: 3120-3127.

Sharon N (2006) Carbohydrates as future anti-adhesion drugs for infectious diseases. Biochim Biophys Acta 1760: 527-537.

Sharon N, Lis H (1989) Lectins as cell recognition molecules. Science 246: $227-234$.

Shevchenko A, Jensen ON, Podtelejnikov AV, Sagliocco F, Wilm M, Vorm O, Mortensen P, Shevchenko A, Boucherie H, Mann M (1996) Linking genome and proteome by mass spectrometry: large- scale identification of yeast proteins from two dimensional gels. Proc Natl Acad Sci USA 10: 14440-14445.

Singh R, Barden A, Mori T, Beilin L (2001) Advanced glycation end products: a review. Diabetologia 44: 129-146.

Stowell CP, Lee YC (1978) The binding of D-glucosyl-neoglycoproteins to the hepatic asialoglycoprotein receptor. J Biol Chem 253: 61076110.

Sun Y, Hayakawa S, Ogawa M, Izumori K (2005) Evaluation of the site specific protein glycation and antioxidant capacity of rare sugar protein/peptide conjugates. J Agric Food Chem 53: 10205-10212.

Varki A (1993) Biological roles of oligosaccharides: all of the theories are correct. Glycobiology 3: 97-130.

Verdonck F, Cox E, Vancaeneghem S, Goddeeris BM (2004) Interaction of fimbriae and enterocytes as analysed by surface plasmon resonance. FEMS Immunol Med Mic 41: 243-248.

Willemsen PTJ, De Graaf FK (1992) Age and serotype dependent binding of K88 fimbriae to porcine intestinal receptors. Microb Pathog 12: $367-375$.

Wong YC (1995) Neoglycoconjugates and their applications in glycobiology. Curr Opin Struct Biol 5: 599-604.

Yacoby I, Bar H, Benhar I (2007) Targeted drug-carrying bacteriophages as antibacterial nanomedicines. Antimicrob Agents Chemother 51: $2156-2163$. 